\title{
A review of recent research on friction, lubrication and wear in the Netherlands ${ }^{1)}$
}

\author{
G. SALOMON \\ CENTRAAL LABORATORIUM TNO
}

\begin{abstract}
Samenvatting
Research wordt door TNO, de drie Technische Hogescholen en door enkele industriële laboratoria verricht. Teneinde alle leden van de ingenieurswereld te bereiken, worden discussies, cursussen en de opleiding van technici door verscheidene verenigingen georganiseerd.

$D e$ voornaamste onderwerpen van werktuigkundig gerichte research zijn: hydrodynamische smering, gegroefde lagers en afsluiters. Voertuigtechnische research heeft tot een nieuwe aanpak in het meten van de wisselwerking tussen weg en band geleid.

De invloed van sporen zuurstof op het wrijvingsgedrag van metalen, evenals smering met behulp van vaste stoffen, worden bestudeerd. Teneinde ,fretting" problemen in de reactor-technologie te kunnen oplossen, werden speciale beproevingsmachines ontworpen. Twee technische ontwikkelingen, van groot belang voor de scheepsdiesel-technologie, zijn afkomstig uit Holland, te weten het hard-verchromen van cylindervoeringen en de emulsie-oliën.

Een summier overzicht van de organisatie van onderhoudswerkzaamheden in de mijnindustrie, bij de hoogovens en de transportindustrieën wordt gegeven. Een operationele aanpak is noodzakelijk bij de keuze van slijtvast materiaal voor specifieke toepassingen.

De door de Overheid gesteunde opleidings- en speurwerkactiviteiten op het gebied van de, tribologie" voorzien in de behoeften van de Nederlandse industrie.
\end{abstract}

\section{Introduction}

Previous review papers [1] on national efforts in this field dealt with research performed in Japan, the Soviet Union and Germany - large ethnographic areas, each with an extensive technical literature in the respective language.

The present survey covers results produced by a much smaller national unit and reported mostly in English. Holland's high population density (12 million inhabitants on $32500 \mathrm{~km}^{2}$ surface area) and the ease of communications facilitate good contacts between technologists.

The nucleation and growth of interactions between research laboratories, technical universities and industry during the last decade will be outlined first. This development is - in the opinion

1) Paper given at the Fourth Convention of the Lubrication and Wear Group, held at Scheveningen 12-14 May 1966. The paper will be published by the Institution of Mechanical Engineers, London, in the Proceedings 1965-'66 Volume 180, Part $3 \mathrm{~K}$.

The paper is reproduced here by permission of the Institution of Mechanical Engineers.

\section{Summary}

Research in this field is performed by T.N.O., by the three technical universities and by a few industrial laboratories. Discussions, refresher courses and education of technicians have been organized by several technical societies to reach all members of the engineering community.

Hydrodynamic lubrication, grooved bearings and seals are the principal topics of engineering research. Vehicle research has led to new approaches in measuring tyre-road interactions.

The influence of traces of oxygen on the friction of metals and on lubrication by solids is studied. Special equipment has been designed to solve fretting problems in atomic energy engineering. Two items of great importance to marine diesel engineering have been developed in Holland, viz. chromium-plating of cylinder liners and emulsion oils.

Organization of maintenance work in collieries, steel mills and the transport industries is briefly outlined. Selecting wear-resistant materials for a specific application demands an operational approach.

Government-sponsored education and research in 'tribology' meet the requirements of Dutch industry.

of the reviewer - a good example of the possibilities, and also of the limitations of highly specialized research on a national level. Most of the research in the field of mechanical engineering, discussed in the following paragraphs, is of recent origin and more advanced than the third topic, that of the slow-moving efforts to understand friction and wear phenomena in terms of materials properties. The latter part of the paper covers briefly the approach to maintenance in Dutch industry.

\section{Organization of research and dissemination of knowledge}

Specialists at T.N.O. and at the technical universities form the nucleus of the discussion groups. The history, present research capacity and activities of the technical societies are now outlined.

The Nijverheidsorganisatie T.N.O. (The Organization for Industrial Research) is comparable in structure with the D.I.R. part of the former Department of Scientific and Industrial Research in 
Britain. In 1950 the late chairman, Professor Dresden [2], set up a team of specialists to study industrial wear problems. This early attempt failed for various reasons, but the first wear research came into being a few years later at the Metal Research Institute T.N.O. This has meanwhile expanded to a well-equipped wear laboratory, surrounded by a large staff of experts in related fields and working with an impressive range of modern instruments. Some of the results are reported in this paper. However, a large number of the investigations performed for Dutch industry remain confidential. In general terms the objects range from parts of household appliances to materials for atomic reactors. Much later the T.N.O. Institute for Mechanical Constructions started the work on bearings which is summarized in this paper. Again, the difficult task of conveying these new ideas to designers in industry has to be performed with considerable discretion. The success of T.N.O. work depends on the close co-operation between the two Institutes. Some complex wear machines needed by the 'Wear Group' are designed by the 'Mechanical Engineering Group'. Several other T.N.O. Institutes perform wear testing, or quality control, in much the same way as they did fifteen years ago [61].

At about the same time that T.N.O. sought ways to perform friction and wear research, the Technische Hogeschool Delft (T.H. Delft) founded two related research centres. Professor Blok introduced the design aspects of rubbing surfaces and of wear [3] and Professor Van Eldik Thieme commenced friction studies in vehicle research. The interplay is illustrated by the work of Muyderman, who specialized first in vehicle research, but wrote a thesis [32] under the supervision of Professor Blok.

These close personal contacts are extended to the staff of the T.N.O. Institute for Mechanical Constructions, which is located in the same block of buildings. The line of thought developed by Blok has now been carried over by R. Bosma to the newly-founded Technische Hogeschool Twente. The third technical university, T.H. Eindhoven, is concentrating on what might be called the Materials Science approach to wear problems. Professor Zaat [4], starting from his earlier experience gained at the Metal Research Institute T.N.O., is building up work on high temperature, wear-resistant materials and on friction properties in a 'hard' vacuum.

There are, of course, other laboratories at Holland's three technical universities where observations on friction, lubrication and wear phenomena are made and occasionally published, e.g. in work on internal combustion engines, tool engineering, industrial lubrication and textile research. Significant contributions that have been brought to the attention of he reviewer are noted below.

Technical education at some twenty 'Hogere Technische Scholen' (H.T.S.) spread all over the country is also at a high level. Frequently graduates from these schools continue their studies at one of the T.H.'s, performing research work with T.N.O. at the same time. At some of these schools the design of lubricated machine components is taught. The standard text corresponds, in a condensed form, with the introductory lectures given at T.H. Delft.

Materials science is apparently a new concept, but in reality the study of material properties has been the purpose of the 'Bond voor Materialenkennis' (Association for the Study of Materials) founded about forty years ago. This technical society, the 'Bond', is sponsored by almost five hundred industries and institutions, and a small number of individual members. Not less than 90 per cent of these sponsors belong, according to their own estimate, to the categories 'very small to medium-sized industries', while the remainder comprise the large national groups and the well-known international concerns. The staffs of these sponsors take part in the various activities of the Society, which consist mainly of (1) lectures by specialists followed by discussions, (2) study groups, (3) committees and (4) free-discussion evenings. The interplay between twelve hundred professionals with an interest in enigineering materials is directed into the four 'classical' divisions of materials: Building Materials, Metals, Polymers, Fibres and Cellulose (Paper) and the four more recent interdisciplinary divisions: Rheology, Lubrication and Lubricants, Wear and Adhesion. The latest addition is the very active study-group on 'Design'.

Discussions are in general on an academic level, but the corporate form of membership chosen avoids discrimination against experienced technologists who acquired their technical knowledge without a formal study. The delivery of lectures (in Dutch, English or German) is stimulated by the fact that neither a preprint nor publication of the text is requested from the speaker, although frequently a printed text is made available at a later date.

The Lubrication Division, founded more than twenty-five years ago, now shares activities with the Wear Division founded in 1954. Topics discussed in the past ten years range from maintenance, special and unconventional lubricants to elasto-hydrodynamic lubrication and space research. A discussion group of lubrication engineers deals with economics, organization and automatic lubrication. The Wear Division first spent some considerable time on the analysis of concepts, on wear types and on testing and in the next stage its lectures covered plastics, bearings, gears, tool wear and wear problems in atomic energy and space engineering. More recently meetings have been held at production centres and factories, thus establishing direct contact between production engineers and research workers.

More than ten years ago the Council of the 'Bond' realized that meetings were not sufficient to bring the knowledge of engineers and technicians upto-date. As no formal education on Materials Science and Technology existed, instructors' manuals were compiled and winter evening classes organized all over the country. The Government had confidence in this enterprise, and thanks to an annual subsidy the fee for these courses has been kept low. In 1965 about a hundred classes on 
more than thirty topics were attented by almost two thousand students; more than a third of these duly passed an examination based on the content of the lectures. One course on ,Industrial Lubrication' is on the undergradute level, two courses on 'Lubrication and Lubricants' and on 'Maintenance' were written to reach mechanics and foremen, and are therefore on shop-floor level. A new course on 'Fuels and Lubricants', specially written to educate teachers at technical schools and motor technicians, attracted only moderate interest.

Returning now to co-operative activities on the academic level, several more groups should be mentioned. The Koninklijk Instituut van Ingenieurs arranges refresher courses, lasting about a week, in many fields. In 1962 one such series of lectures with contributions in German, Dutch [16, 29, 33] and English was devoted to 'The hydrodynamically lubricating film as an element in design'. The printed discussions make clear that these courses were given by specialists to an audience of experts. A course on 'Wear-reducing surface layers' will be held in 1967 in co-operation with the 'Bond'.

The 'Werkgroep Lagers' (Working Group on Bearings) of the Federation of the Metal and Electrical Industries (The Hague) issues information sheets on rubbing machine parts. Five parts have been issued up to the present: terms and definitions, examples of bearing design, Plastics as bearing materials, bibliography on thrust and journal bearings, and fundamentals of the hydrodynamic theory of bearings. Obviously it will be difficult to keep some of these sheets up-to-date.

The 'Motortechnisch Colloquium' (Colloquium on internal combustion (i.c.) engines) was created thirty years ago. Participation is by invitation only, and lectures and round table discussions are generally not published. A free opinion can therefore be formed by participants inter alia on lubrication and wear of engines.

The results of research reported in the following should be weighed against this background, and some other co-operative efforts, as will be shown.

\section{Engineering research \\ Rolling friction}

De Pater has dealt with the theory of contact between two elastic bodies which are rolling and slipping with respect to each other. Two cases, that of large ,creep' and the other extreme, the case of vanishing 'creep' accompanied by a slight spin, were considered in detail [5]. A vanishing Poisson's ratio, equal elastic constants and circular contact areas had to be assumed in order to make the three-dimensional problem accessible to mathematical analysis. Kalker later proposed a theory wherein Poisson's ratio is unrestricted [6]. However, a generalized theory for overall slip and spin is not yet available. Kalker therefore developed a numerical method which is valid for any distribution of the contact area in adhesion and slip [7]. Several cases were calculated with the aid of a fast computer, and compared with K. L. Johnson's experimental values. (For a recent survey by John- son, see reference [8].) Good agreement was obtained for the total tangential force, while the calculation of local slip was less accurate. Some predictions were made also for the case of bodies having unequal elastic constants; further details are to be published [9].

\section{Hydrodynamic lubrication}

Review papers were contributed by Blok to the 1957 Lubrication Conference [10] and the 1958 Conference on Gearing [11] arranged and held by the Institution of Mechanical Engineers. This series has been continued by Blok en Theyse.

The paper presented by Blok at the occasion of the 1960 General Motors Symposium [12] deals in great detail with rolling and slippage in cylindrical counterformal surfaces. Emphasis is on dimensional analysis of the correlating variables. Areas of application are illustrated by case studies. Special attention is paid to the type of lubrication preponderant in pure rolling. The author concludes that free-rolling, i.e. when one roller is driven by the contact, is incompatible with full hydrodynamic lubrication. Another case study refers to laboratory skidding experiments of tyres on wet road carpets.

The now classical concept of flash temperatures has been reviewed by Blok at several Symposia and the full paper contains some interesting notes on the history of the theory [13].

A new theoretical tool for the designer is described in an extensive contribution by Blok to the 1963 University of Houston Symposium [14]. This review deals mainly with items not previously published. It consists of two parts: 'Inverse problems of hydrodynamic lubrication' and 'Design directives for lubricated flexible surfaces'.

Problems are defined as 'inverse' when a given distribution of film pressures is imposed on the film. The Reynolds equation is reduced, in the simplest case, to a cubic with film thickness as the unknown; algebraic solutions then suffice for assessing the film profile. The author first develops the engineering logics of the new concept, and then proceeds to illustrate its application to a variety of hydrodynamic wedging actions and to the elastic response of lubricated flexible coatings.

Results on dynamically loaded bearings obtained by Blok [15] have not yet been made available in print. Again the conceptual approach is directed at a better and more convenient control of film thickness, and certain orbital characteristics of the iournal centre in dynamically loaded bearings. The dynamic characteristics of a journal bearing are described by a 'squeeze diagram' which consists of a family of 'squeeze paths'. The latter are assessed experimentally by subjecting the non-rotating journal to a set of squeezing conditions. Next the geometry of the cyclic orbit of the journal centre is discussed in terms of the theory of nonlinear oscillations. These topological methods are subsequently combined with a consideration of the 'impulse capacity' rather than the conventional load capacity of the oil film. The author concludes that in certain cases the minimum film thickness, 
e.g. in gudgeon-pin or crosshead-pin bearings, is independent within wide limits of viscosity, frequency or engine speed.

Theyse's first review paper [16] linked the now accepted theory with recent advances (1960-1963) made in other countries, notably in Germany. The second paper [17] gives, in an abridged form, the prisent state of the theory on elasto-hydrodynamic lubrication with emphasis on practical aspects. The remainder of the review contains a summary of experimental work performed at the Laboratory for Machine Components, Delft:

(1) The transition from partial to full-film lubrication was measured in a ball-bearing test rig; variables were load, slip ratio and lubricants.

(2) Pitting tests on gears performed in a standard I.A.E. rig. Lowering the bulk temperature of the lubricating oil from $95^{\circ}$ to $85^{\circ} \mathrm{C}$ increased the pitting life by a factor of 3 .

(3) Scuffing tests on gears led to the construction of a rig suitable for incremental loading during continuous running at frequencies below $200 \mathrm{~Hz}$. It appears that the onset of scuffing is, by this technique, moved to higer loads and higher bulk temperatures.

As the primary task of a university laboratory is education, much energy is devoted by Blok and by Theyse to the design of experiments that can be handled by students. While specific results do not necessarily deserve mention on an international level, such work, and corresponding surveys in Dutch and German, on air bearings, foil bearings, seals and liquid metal lubricants [18-21] is of great importance in preparing designers for their future task. For convenience, some work on material properties, to be discussed later in a systematic way, will be mentioned now.

In co-operation with the Engineering Research Department of 'Werkspoor N.V.', Amsterdam, the life of bearings was studied on a Glacier 'Sapphire' machine as a function of loading and thermal cycling. As expected [22], certain inferior fatigue properties of tin-based white metal depend on the thermal anisotropy and size of tin crystals. Repeated thermal pre-cycling to $80^{\circ} \mathrm{C}$ reduced the fatigue life of such bearings considerably [23].

The designer, who has to make a choice from available lubricants, is faced with the imperfections of time-honoured empirical viscosity, equations. The viscosity index is no longer considered a reliable criterion for viscosity-temperature relationships. Roelands, Blok and Vlugter [24] have proposed a new empirical equation that contains only two parameters. The first depends on the dynamic viscosity at a standard reference temperature; the other is a measure of the variation of viscosity with temperature. This 'slope index' offers a practical advantage, either in the comparison of homologous groups of synthetic lubricating oils or in comparing miscellaneous liquids (e.g. mercury, gallium, water and bitumen) over a broad range of temperatures.

The dynamic nature of an elasto-hydrodynamical- ly lubricating film between a flexible seal (O-ring) and a reciprocating rod can be followed by optical interference measurements, at least at low fre quencies $(1 \mathrm{~Hz})$. The coloured photographs of such interference patterns have been used in the preparation of drawings, which have been combined to form a slow motion picture [25]. This film illustrates the 'breathing' of the load-carrying lubricating film.

\section{Bearings and seals}

The Reactor Centrum Nederland sponsors a (classified) atomic energy project involving the use of an ultracentrifuge. An improved type of pintle thrust-bearing has been developed for this purpose by the Research Laboratory of Werkspoor N.V., Amsterdam [26]. The geometry of the spiralgrooved bearing permits the lubricating fluid film to exert a pumping action (see Boon and Tal [28]) at high speeds of rotation of the vertical shaft of an ultra-centrifuge.

The study of gas bearings has become important in this context. The same group, in co-operation with the Laboratorium voor Massaspectografie, Amsterdam, developed a method of measuring film thickness in gas bearings [27]. Capactance changes between the sliding member and probes mounted in the stationary member were measured and displayed on an oscilloscope screen. The photographs thus obtained serve as a basis for calculating the eccentricity of the journal centre, e.g. in the studv of whirl.

Boon and Tal advanced the principle of the 'viscoseals' [28]. Spiral grooves (of rectangular crosssection) were machined on a shaft. When the latter was fitted in a housing with a clearance, and next rotated, the (screw) pumping action of the grooves prevented leakage of the sealing fluid through the clearance. Earlier Baron had measured this effect for the special case of sealing gases against a vacuum [29]. Data are presented in a dimensionless diagram, and optimum design parameters have been derived. A spiral groove vacuum seal has been patented [30]. Baron has also studied the behaviour of tilting-pad bearings at high speeds $(50 \mathrm{~m} / \mathrm{s})$. It has been shown that the influence of elastic and thermal distortions must be taken into account. Results obtained by Baron are included in a review paper [31].

When designers at Philips Laboratories required a wear-resistant thrust bearing able to take up a moderate load from a shaft rotating in a vacuum at high speeds, Muyderman and his associates set out to solve this specific problem. They were led to grooved bearings and found new applications for this principle. The first chapter of Muyderman's thesis deals with earlier work performed at the Atomic Energy Research Establishment in Britain, and the closely related theory of viscoseals developed by Boon and Tal [28] in Holland. In the following chapters of this monograph [32] an accurate calculation of true spiral grooved bearings is given, including the number of grooves, coefficient of friction and load carrying capacity of inward and outward pumping types. A large number of specimen calculations has been included. 


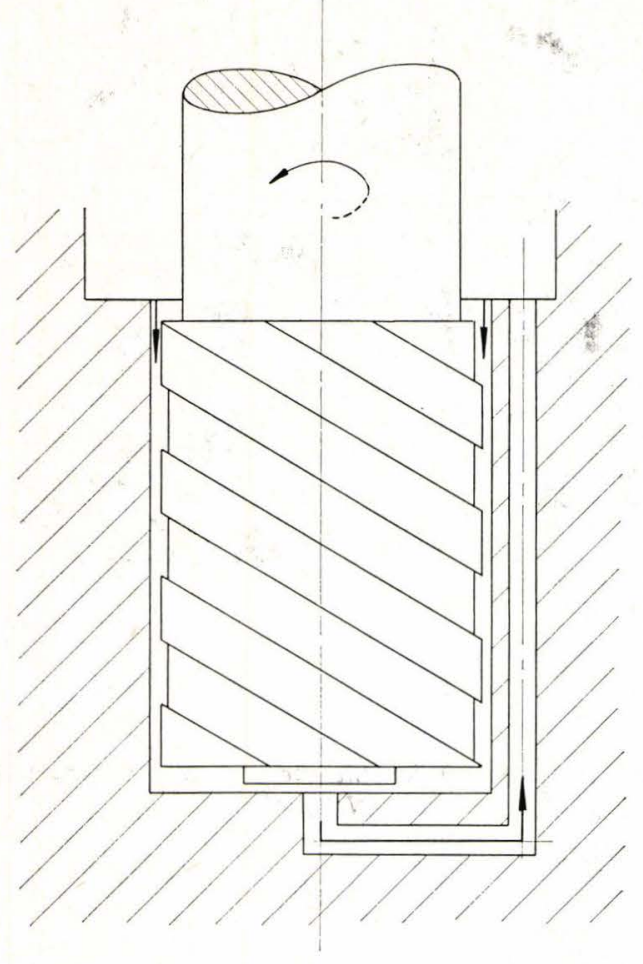

Fig. 1. New design of a thrust bearing (T.N.O.-Institute for Mechanical Constructions [39]).

In this throttled, leakage-controlled bearing, lubricant is pumped downwards, while building up pressure. Next, lubricant is forced into the clearance space below the bottom of the journal. The pressures thus generated counteract axially directed external forces. The lubricant flows radially inwards and passes through the clearance below the step, thus controlling the leakage and, therefore, the pressures. Then equilibrium of external forces and the resultant of the pressures become stable. One of the distinguishing features of this bearing is its pumping capacity; a separate lubricant pump is redundant.

In the second paper [33] spiral-groove bearings are described against the broad background of bearing history and the more recent development of gas bearings. Another recent review. [34] deals with laboratory experiments and the application of gas-, oil- and grease-lubricated grooved bearings.

Muyderman's contribution to this conference [35] covers similar ground. Practical applications of these inventions are extensively studied. A new type of a controlled external restriction giving infinite stiffness, has been successfully tested for use in hydrostatic bearings. Work on flat, self-acting, air lubricated sliding shoes of special shape for use in memory drums and discs gave excellent results.

The application of grooved bearings in major industrial projects is also an activity of the Institute T.N.O. for Mechanical Constructions; part of the theoretical background has been published by Hirs. The optimum stability characteristics for near-centre operation of self-acting grooved journal bearings were predicted and confirmed by experiments [36]. The stability of the bearing depends inter alia on the film-pressure component in opposition to the eccentricity vector. Externally pressurized groove bearings have also been developed. If grooves are inclined, e.g. herringbone grooving, the through-flow of lubricant exerts viscous forces in the direction of motion and these can be used to produce inherent friction compensation. Assuming that all available energy is transformed into viscous heat, criteria for optimizing dimensionless groove parameters have been postulated. Calculations were checked by experiments with a continuous viscometer [37]. The behaviour of partly grooved bearings with external pressurization will be discussed at this Conference [38].

Taking the visco-seal as a starting point, Hirs studied the correlation between film-pressure distribution, viscous heat generation and stability characteristics of grooved bearings. Dimensionless parameters were used throughout the calculations. An advantage of these concepts is that optimization of conventional as well as of new types of visco-seals and grooved bearings can be performed with sufficient accuracy, as verified by experiments. The practical advantage of grooved seals, grooved thrust and journal bearings is also shown in some detail [39].

\section{New designs}

While new solutions for friction and wear problems are sometimes indicated only in information sheets, two major achievements have now been fully described in the technical literature.

The 'Variomatic' automatic transmission on the 'Daffodil' car developed by Van Doorne constitutes a radical departure from convention in power transmission. Davies [40] has recently given a brief description of the design. A full discussion by Ludoph is available [41]. The forces acting on the V-belt pulley have been calculated. Since the normal force which can be transmitted is not constant over the whole contact surface, a new quantity, the 'pinching pressure', has been introduced. Not only was the predicted mechanical effect found to be of the expected magnitude, but the correct choice of belt material was of equal importance. The temperature at the friction interface reached $80^{\circ} \mathrm{C}$. Neoprene rubber belts can operate at this level without appreciably accelerated aging. Although the development of a gas refrigerating machine by Philips Research Laboratories dates back more than ten years [42], new types, suitable for very low temperatures [43] or for the production of ultra-pure hydrogen [44] became available only recently. The introduction of a hydraulic drive system has eliminated any piston wear. More important is, however, the design of a positive seal which separates the working gas (helium or hydrogen) hermetically from the surrounding space, and prevents at the same time penetration of impurities into the expansion chamber [45]. The seal [46] consists of a (polyurethane) rubber membrane fastened to the cylinder wall and the piston. The membrane is supported by a liquid. The support determines the shape and deformation of the membrane. These auxiliary constructions permit 


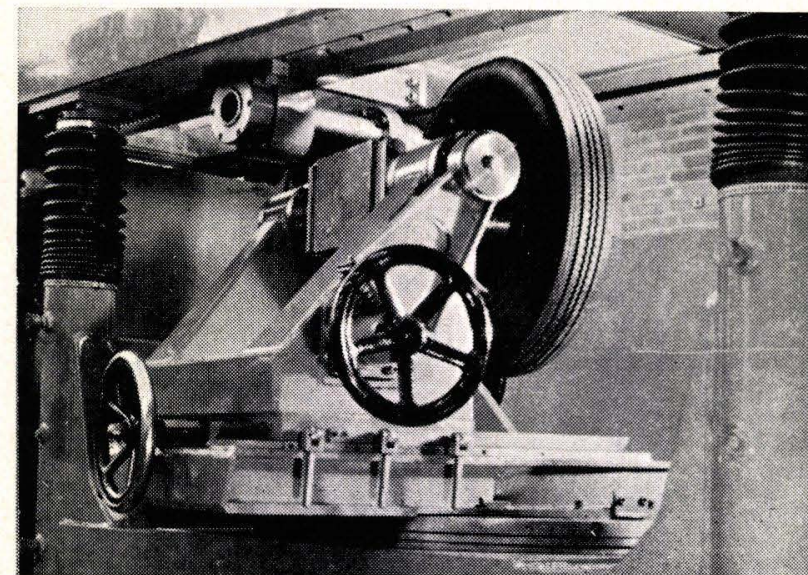

Fig. 2. Measurement of tyre-road interaction (Vehicle Research Laboratory, TH Delft [47]).

The test-tyre is mounted on a sledge and pressed against a glass plate. Deformation patterns in the contact zone are observed through this plate. Forces acting on the tyre are measured with instruments built in the sledge.

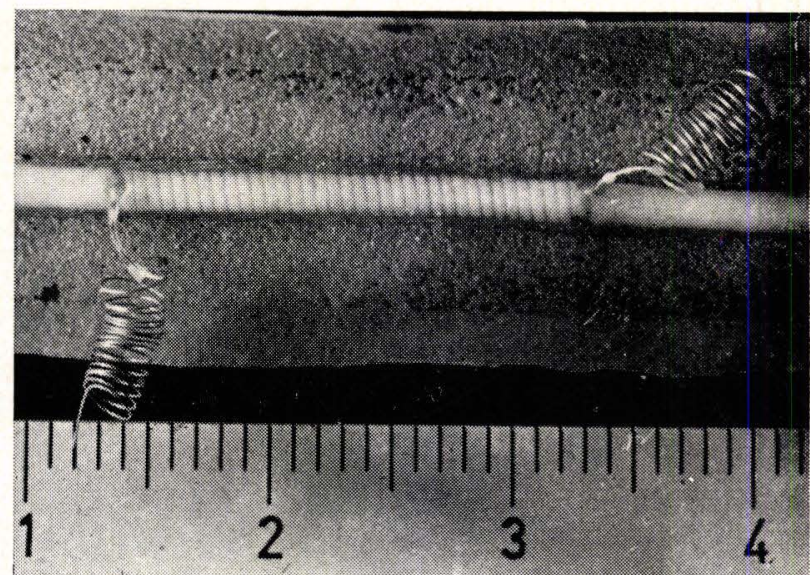

Fig. 3. Rubber strain gauges for the measurement of strains in tyres (TH Delft and T.N.O. [47]). application of a pure gum rubber, even when large pressure differences exist.

Until recently membranes in positive seals consisted of fibre-reinforced materials, suitable only for applications with slow reciprocal movements, and even then they have a moderate fatigue life. The application of a supporting liquid, with an adjustable level, makes it possible to calculate the bending stresses in the membrane and to optimize thickness and maximum strain. Fatigue life at moderate temperatures is excellent; the seals are moreover easy to replace. The same positive seals are also used in certain oil-free compressors [46].

\section{Vehicle research}

The Vehicle Research Laboratory T.H. Delft is concerned mainly with theoretical and experimental studies of tyre-road and rail interaction, riding comfort and safety, as well as the testing of components, e.g. springs, shock absorbers, brakeshoes and brake-linings, tyres and car bodies. In addition to testing machines, an analogue computer is available for theoretical studies and a fourteenchannel tape recorder is used for large-scale measurements.

The tyre-road interaction has been treated systematically in a series of publications. The first paper by Van Eldik Thieme [47] dealt with the equipment available for tyre research. A novelty is inter alia the preparation of small rubber strain gauges suitable for recording large extensions (about 20 per cent), a result of co-operative research with the T.N.O. Institute for Mechanical Constructions. Most of the more conventional testing rigs, e.g. the Gough tester, have been improved to allow for more accurate measurements of stress and strain. The foundation for an exact description of tyre behaviour was thus laid. Next Van der Burgt [48] studied the interdependence of car and tyre. The non-linear behaviour of bouncing tyres was measured and the influence of abrupt changes in the stiffness of tyres, owing to bouncing, has been approximated.

Van der Valk [49], adopting the tyre-makers' point of view, has dealt with the interaction of available materials and tyre construction: special attention was paid in this survey to problems of friction and slip. A second contribution [50] again dealt with the numerous factors which tyre manufacturers have to take into account. Riding quality and cornering ability are expressed in terms of physical quantities, which in turn oan he linked to ply-structures.

The latest contribution is an analysis of 'shimmy' phenomena by Pacejka [51]. They are apparently two kinds of shimmy: the one originating in tyre elasticity and the other attributed to gyroscopic coupling. Experimentally, these phenomena were examined by combining studies of mechanical models with measurements on test vehicles. Pacej$\mathrm{ka}$ analysed the behaviour of three non-linear elements in the car:

(a) the tyre characteristics,

(b) the Coulomb friction in the king-pin bearing, and

(c) the clearance in the wheel bearing.

Two methods were used to solve these non-linear problems: the technique of equivalent linearization and the application of an analogue computer. Discussion of material properties in this series of papers was essentially restricted to elastic moruli and to the stiffness of constructions. Savkoor [52], when dealing with the friction of rubber, introduced the element of time-dependence, viz. viscoelasticity as related to tyre hysteresis. This general 


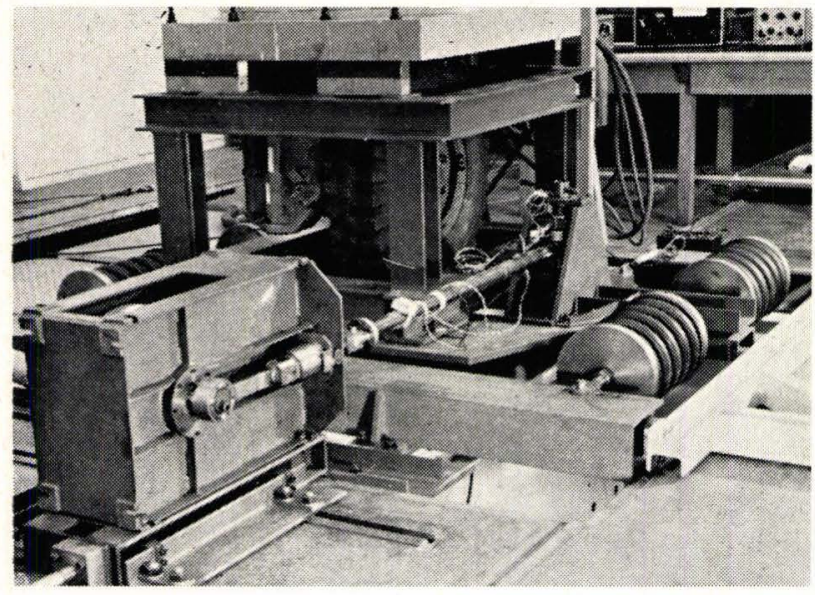

Fig. 4. Test rig for studying the "shimmy" of tyres (TH Delft [51]).

The test tyre is placed on a rotating drum. The test rig, constructed as a mass-spring system, can rotate in the horizontal plane. The assembly is excited by a pulsator in its own frequency.

concept is linked in his second paper [53] with an experimental study of cornering forces at very low speeds on dry and on well-lubricated surfaces with different roughness. The influence of hysteresis on tyre 'adhesion' is shown and a classification of tyre-wear types is given.

The Rijkswegenlaboratorium, Delft (Government Road Research Laboratory), does not, in general, publish its findings with regard to friction properties of road surfaces. In this context, Obertop [54] has suggested that the loss of braking efficiency on wet roads might be a consequence of steam formation at the tyre-road interface. This hypothesis of vapour-lubricated areas is supported by some calculations.

\section{Materials research}

\section{Analysis of wear problems}

The 'International Symposium on Abrasion and Wear' [55] held in 1951 at the Rubber-Stichting was the first meeting of its kind to be held in Holland and included some work carried out in this country. Blok [56] emphasized the economic nature of all industrial wear problems, a theme worked out later in greater detail [3]. Broeze [57] covered work carried out before the war on chemical wear, Brunt [58] linked physical properties of lacquers to their abrasion resistance, and Salomon [59] dealt with deterioration due to dynamic fatigue of fibres and the stress corrosion of plastics. Of these only Blok's lecture had a follow-up through further research. The meeting was, however, instrumental in the formation of the Wear Division of the 'Bond'.

Blok and Salomon [60] analysed a survey made by the 'Bond' which had been based on seven hundred answers received from one hundred industries. Interest was mainly stimulated by maintenance problems and by the lack of good criteria for wear. More information is required on the wear behaviour of plastics and rubbers. Curiously enough, damage to industrial flooring caused considerable concern (this, however, was prior to the use of epoxy-resins for repair work).

Salomon and Beekhuis [61] analysed the theoretical concepts of wear and separated mechanical, chemical and design factors from operational conditions. These studies were stimulated by attempts made in Germany to standardize wear testing [62]. Later the essence of this approach was published in English [63]. The initial phase of the O.E.C.D. work reported by de Gee [64] at the present conference did not differ much from the experience of ten years ago. In fact, the 1951 survey was based on the same [60] questions. The uncertainties introduced by verbal concepts can influence the design of experiments [65]; the interdisciplinary nature of wear research demands special care in the usage of terms and definitions, which are being clarified now by a group of experts [64].

\section{Testing}

Motives for testing can be $(a)$ production control, (b) quality control, $(c)$ evaluation of new products, (d) selection of the most suitable product in a given friction and wear situation, or $(e)$ trouble shooting; another motive is the urge to substitute qualitative concepts by reproducible but frequently meaningless data. When Braber and Salomon [55] compiled information on more than a dozen wear testers available at that time in this country, they concluded that most of these machines were 'hybrids' producing data neither related to physical properties of materials nor to an actual wear situation. Only a few progressive contributions have since been published.

A claim is frequently made that new plastics used in flooring materials have an outstanding wear resistance. On the initiative of an independent user, Frommes of Luxembourg, an 'International Study Committee for Wear Tests of Flooring Materials' was formed to examine more systematically the discrepancies between different machines. Harper of the British Building Research Station reviewed methods of testing exhaustively [66]. Service trials were performed in Germany: Ratiobouw, Rotterdam, served as a centre for the nineteen participants who, after compiling all results, came to the following two conclusions [67]:

(a) The large majority of the seventeen abrasiontesting machines are unsatisfactory, when used to compare the wear of a wide range of different flooring materials, such as that of the present investigation and, a fortiori, to judge new materials.

(b) An abrasion machine can provide valuable results for one type of flooring material or one material in different qualities without being suitable for comparative testing of the wear of different materials.

This means that of the five targets mentioned above, only the first 'production control' can be implemented by abrasion testing, and perhaps the second 'quality control' with certain reservations. 


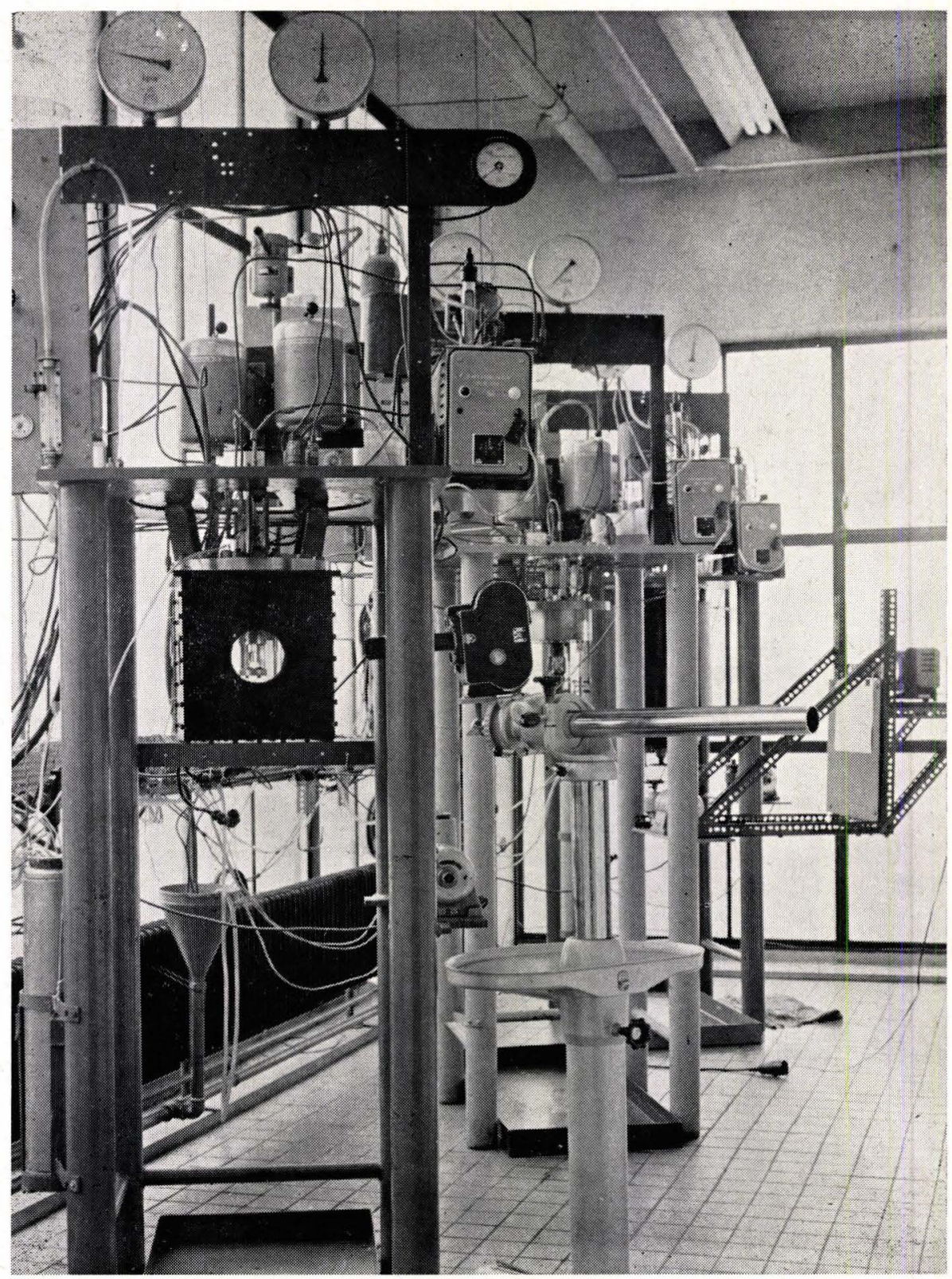

Fig. 5. A new fretting machine (Metal Research Institute T.N.O. [70]).

The photograph shows three identical machines. The one in the foreground is fitted with a dummy friction chamber and through the window the friction couple can be seen. A film camera is mounted to record the movements of the specimens. A combination of reciprocal movements with impact loading can be produced. The machines operate in gases or liquids up to $450^{\circ} \mathrm{C}$.

Evaluation of new materials has to be performed by service trials. The latter can be accelerated by exposure of these materials in railway [58] or subway stations; in fact, Dutch raw materials are being tested in L.T.C. stations. The conclusions of the Committee should also be of value in the testing of metals and of inorganic materials. The remainder of the testing activities correspond to the positive, the second, conclusion of the Committee.

May [68] modified the Akron-Croydon abrasion tester for rubber compounds. By adding a magnetic brake to the design of the tester, power transmission was kept constant. Statistical correlation of abrasion test results with road tests of natural and synthetic (SBR 1500) rubber tyres was significant. Perhaps the most interesting data are those of the road tests with a small European car. At low loads and speeds. the wear resistance of the two rubbers is nearly identical. On the race track, under medium and high severity conditions, the synthetic rubber tyre is twice to three times more resistant.

The 'Nederlandsch Scheepsbouwkundig Proefstation', Wageningen (Netherlands Ship Model Basin), carries out systematic tests in a cavitation tunnel. A special working section for testing hydrofoils has been built in [69].

A set of automatically controlled fretting machines for testing materials to be used in an atomic reac- 


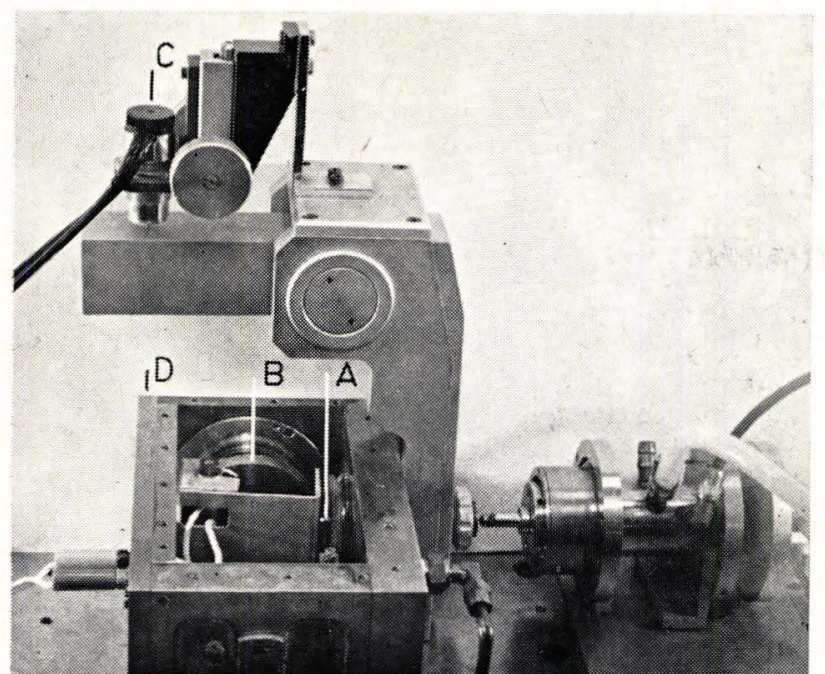

Fig. 6. Measurement of sliding wear at medium loads (Metal Research Institute T.N.O. [73]).

Only the core of the machine is reproduced here (driving system and torque recorders are not shown). $A$ pin $(A)$ can be pressed against a rotating ring $(B)$ by means of a lever-piston system. Decrease in height of the friction couple, due to wear, is continuously recorded with a differential transformer $(C)$. The closed friction chamber (D) (lid removed) is flushed with pre-conditioned gas. Heating of the couple up to $200{ }^{\circ} \mathrm{C}$ is possible.

tor of the ORGEL-type has been developed by the Metal Research Institute T.N.O. [70]. Even more complicated machines to study the behaviour of materials for fast, sodium-cooled, breeder reactors have been built by the same group.

\section{Mechanisms of wear}

In many recent investigations, the transition from 'mild' to 'severe' wear has been studied. These words have no precise meaning, but a knowledge of parameters that cause a rather sudden increase in the rate of wear is of practical importance. De Gee and Zaat [71] studied the adhesive wear of leaded $\alpha$ brasses against steel. They found indications that the chemical composition of the very thin oxide layers which form on the brass surface during sliding (either zinc or copper oxides) determines the course of the wear process. As a consequence, the wear of certain ranges of alloys in argon is very much lower than the wear in an oxygencontaining atmosphere. These systems are, of course, too complicated to trace any quantitative correlation between materials properties and wear rate. Therefore, de Gee [72] started anew from the much simpler system of silver-gold alloys (pin) against steel (ring). As iron is insoluble in silver while it is soluble in gold, a correlation between alloy composition (and therefore solubility of iron), friction and wear was expected and indeed found. When about 40 at. per cent gold has been alloyed with silver, the solubility of iron becomes measurable. At this point, friction of the couple increases suddenly, silver-gold alloy is transferred to the steel and the rate of adhesive wear becomes six to eight times faster, provided that the experiments are performed in pure argon. In air, however, even pure silver is a very poor running mate for steel, transfer of silver to the steel occurring, accompanied by high friction and a high rate of wear. In order to clarify the mechanism by which oxygen exerts its detrimental influence, de Gee and Begelinger [73] measured the influence of small quantities of oxygen in argon on friction and wear at various temperatures. It was found that 0.1 per cent oxygen is sufficient to initiate the transfer of silver to the iron surface. The formation of an 'iron surface activated by oxygen' is responsible for this effect and the resultant increase in friction and wear. General studies on the role of mutual solubility of the sliding components and on the role of oxygen are now in progress.

Sintered aluminium powder (s.a.p.) is a potential construction material in nuclear reactor technology because its neutron absorption is low, whilst it retains its strength at elevated temperatures over long periods. One problem in design was whether a contact s.a.p.-s.a.p. in certain parts of the construction would wear rapidly under the influence of complex vibrations. De Gee, Commissaris and Zaat [70] constructed a series of fretting machines for this purpose, in co-operation with the T.N.O. Institute for Mechanical Constructions. The testpieces were subjected to normal or torsional vibrations, or a combination of both. As measurements had to be performed in gas or in terphenvl at high temperatures and over long periods, all variables were recorded automatically. The wear rate of s.a.p.-s.a.p. couples was relatively low when subjected to either torsional or normal impacting vibrations, but very high under conditions of combined vibrations. The fine debris powders, typical for fretting, separated the contact surfaces to some degree without causing appreciable abrasive damage, but they were removed rapidly when combined vibrations were applied. The machines have also been used to solve conventional industrial fretting problems.

The erosion resistance of materials is a matter of great practical importance and has been studied by Wellinger and his associates in Germanv for many years [74]. Recently Brauer and Kriegel have turned their attention to the wear of feed lines for the transport of granular material [75]. A general theory relating wear to volume properties of materials was developed by Bitter [76]. An earlier attempt had been made by Finnie [77], who concluded that maximum erosion of ductile materials can be predicted by assuming a cutting mechanism; the erosion of brittle materials was not yet amenable to a similar analysis. In the first part of this paper, Bitter developed a theory of 'deformation wear' in the absence of cutting wear. The wear resistance of glass and of concrete are predicted correctly from the elastic properties of the materials. In the second part a more elaborate theory than that used by Finnie was proposed and tested on a series of metals. Finally, Bitter showed how erosion phenomena observed on tubes or valves could be understood by assuming a superposition of both processes. 


\section{Liquid lubricants}

In contrast to the abundance of technical information on commercial lubricants, very little original research has been published. The viscosity criterion proposed by Roelands et al. [24] has already been mentioned. Bosma and Naylor [78] measured the influence of structural viscosity on the load-carrying capacity of mineral oils. The decrease in viscosity with increasing shear rate, first discussed in this context by Umstätter, was confirmed. However, the beneficial effect on a plain journal bearing under conditions encountered in actual use was much smaller than that predicted by Umstätter. At the present Conference, Broeder and Heijnekamp [79] deal with the effect of deliberately added abrasives on a plain journal bearing. The results suggest that the abrasive wear in lubricated bearings does not differ essentially from abrasive wear in unlubricated systems [80]. Therefore, even highly effective lubricants cannot protect bearings against the damage caused by abrasives. Lancaster (Farnborough) has recently studied the potentially abrasive nature of solid lubricants [81]. Taking the two papers in conjunction, it would seem that removal of abrasive solids, above a certain limiting particle size, is the only effective means of protecting a lubricated system, irrespective of the nature of the lubricant.

\section{Solid lubricants}

Equipment used for metal-to-metal friction studies is suitable for an analysis of lubrication with solids. These machines have been gradually perfected. The 'fourth generation' of pin and ring machines developed at the Metal Research Institute T.N.O. have the following characteristics: accurate recording of forces, automatic photography of surface areas, electrical resistance measurements and an accurate control of the atmosphere; special machines for friction experiments at very low loads; continuous analysis of the atmosphere and metering devices for vapours; rubbing-in machines for coating surfaces reproducibly.

Salomon, de Gee and Zaat [82, 83] have traced the origin of $\mathrm{MoS}_{2}$-film failure on the molecular level to oxidation, and on the microscopic level to blistering. The latter process can take place only when a continuous lubricant film is formed. Oxidation accelerates film formation. The breakdown of graphite films is also attributed to blistering, but graphite films are less regular and rather brittle. Addition of graphite to $\mathrm{MoS}_{2}$ had, under the conditions of these comparative tests, no advantage.

The comparison was recently extended to the disulphides and diselenides of molybdenum, tungsten and niobium. Large differences in friction properties were observed at very low loads and they could be reversed by a change in atmosphere [84]. Jellinek and his school at the University of Groningen have established certain regularities in the layer structures of these chalcogenides [85]; a correlation with their friction properties has been suggested [86].

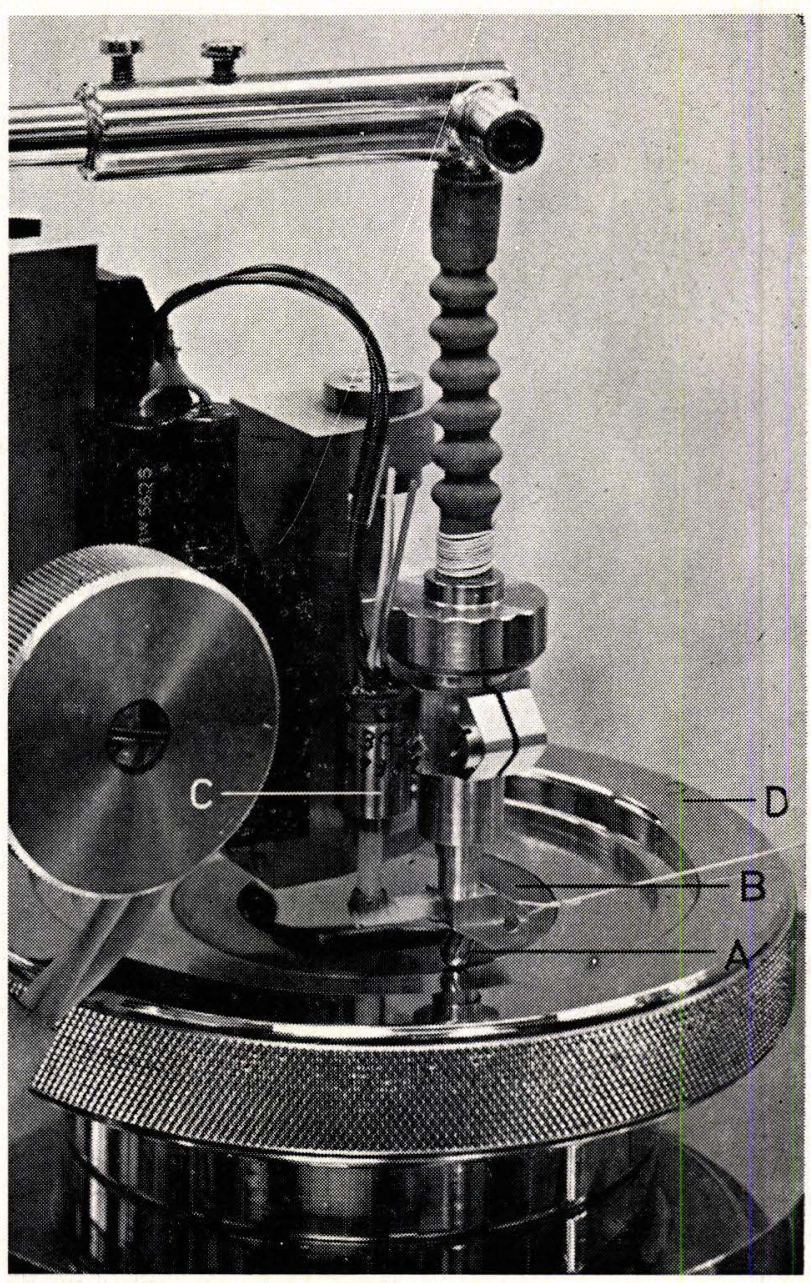

Fig. 7. Measurement of sliding wear at low loads (Metal Research Institute T.N.O. [84]).

Only the working of the friction couple is shown here. $A$ pin $(A)$ is pressed against the disc (B) by a gas pressure loading device. As in Fig. 6 the loss in height is recorded by a differential transformer $(C)$. The disc is mounted on a turntable (D) equipped with temperature controls.

The lubricant properties of phthalocyanines have been studied. Certain halogen-containing compounds of this class are better than graphite, but they are mostly inferior to $\mathrm{Mo}_{2}$ [84].

\section{New processes and new materials}

Two inventions, decisive for the further development and use of marine diesel engines, came from Holland: the chromium-plating of cylinder liners due to Van der Horst, and the emulsion oils for lubricating these cylinders patented by the Bataafse Petroleum Maatschappij [87]. Van der Horst's group combined the first with the second invention by taking out a patent on the addition of bichromates to emulsion oils [88]. The use of heavy residual oils with a high sulphur content as fuels has led to an increased cylinder wear of diesel engines. Chromium-plating of machine parts is useful only if electrochemical formation of a galvanic cell is prevented. Sulphuric acid from the combustion products can act as an electrolyte. 
Therefore alkaline (emulsion) oils are now used generally.

While the electro-plating of worn parts with iron [89] and chromium-plating of those repaired or of new linings and pistons are proprietary processes, some technical information is available that is sufficient to indicate the principles involved [90, 91].

A detailed report on the development, properties and application of emulsion oils for low-speed diesel engines was given by Van der Zijden and Kelly [92] ten years ago. This unique and revolutionary method of cylinder lubrication' [93] has since been improved considerably, but no additional information has been published from this country. It may, however, well be that the advances made in emulsion oil technology will make chromium-plating of cylinder liners less attractive economically.

No information on the friction and wear properties of rubbers and plastics produced in Holland is available, except for Nylon 6. Steinbuch [94] has presented a detailed account of the friction properties of Nylon 6, the influence of external lubrication with grease, oil or water, the improvements by $\mathrm{MoS}_{2}$ and graphite fillers and the interaction between external and internal lubrication. Some of his observations on the effects due to the hardness of solid lubricants agree well with the recent study by Lancaster [81]. Work on the influence of glass-fibre reinforcement in Nylon 6 bearings is now in progress [95].

No original contributions have been made in the field of graphite, molybdenum disulphide $\left(\mathrm{MoS}_{2}\right)$ and polytetrafluorethylene (p.t.f.e.) lubrication, but the engineering community has rapidly made full use of these lubricants. The application of polytetrafluorethylene in expansion bearings of the IJ-tunnel (Amsterdam) has received considerable publicity [96].

\section{Combating wear in industry}

A competitive, cost-conscious industry is also wear-conscious. Many 'problems' discussed by the members of the ,Bond' some years ago have since been eliminated by a change in design or by the application of new (solid) lubricants. Surface hardening and hard-facing techniques have been adapted to local situations. A comparative study of flame-spraying versus electric arc and plasmaspraying has been reported [97]. The electric arc was favoured previously in countries with a shortage of oxy-acetylene supply. It appears that the technique is convenient, once a stable arc is produced, for repair work on board ships. Plasma-jet spraying has, in addition to the higher working temperatures, the advantage of a clean and rapid coating technique. With a growing understanding of the structure of wear-resistant layers, emphasis is shifted from repair to preventive maintenance. Wear problems in production engineering are dealt with by the 'Centrum voor Metaalbewerking' (Centre for Metalworking) of the Metal Research Institute T.N.O. in co-operation with the corresponding laboratories of the Technical Universities
Delft and Eindhoven [98]. Conventional and new production methods are studied, inter alia the wear of production machines and its prevention, tool wear and the quality of cuttings oils. Although some contributions of the said Centrum have found international recognition, these studies are primarily performed to serve Dutch industry. Low cost co-operative projects have been set up, e.g. merit-rating of coolants.

The 'Staatsmijnen' (The State Coal Mines) are a typical 'wear-conscious' production centre. Preventive measures taken are conventional, such as the use of harder surfaces or minor changes in construction. The interesting point of a survey [99] was the operational nature [61] of maintenance projects. As predictions from laboratory experiments are insufficient, observers have to be placed on the spot. Foremen in underground repair shops have to be persuaded before an obvious but apparently 'new' method can be introduced, and machine parts have to be exchanged for trial runs in production units. Emphasis is on communication within a large, highly organized social group rather than on research.

The 'N.V. Koninklijke Nederlandse Hoogovens en Staalfabrieken' (Roval Netherlands Blast-furnaces and Steelworks) have similar problems. De Vries [100] discussed methods of preventive maintenance used some ten years ago. As a follow-up, he tried to organize information sheets on wear-resistant parts used in workshops.

This was carried out in close contact with maintenance engineers of 'Staatsmijnen'. However, growth of K.N.H.S. was too vigorous for such time-consuming projects. Modern techniques of automatic lubrication are used, and the cost factor is considered carefully. At present, the application of aluminium-complex greases is being studied. Lithium greases decrease in shear strength and stability above $120^{\circ} \mathrm{C}$, while the aluminium complexes are stable up to $180^{\circ} \mathrm{C}$.

The third largest area of maintenance is transportation. A good deal of the Dutch i.c. engines are either imported or built under licence. Incentives to perform original research are therefore few; the trend is to follow manufacturers' and suppliers' specifications. Users co-operate with international committees and research corporations. Doppenberg [101] has given an account of the great variety of greases, oils, maintenance fluids and calibration liquids which the Royal Dutch Airlines K.L.M. are forced to use. Reduction in the number of standards and of lubricants needed could lead to substantial savings.

Shipyards and shipping trade co-operate in the T.N.O. 'Studiecentrum voor Scheepsbouw en Navigatie' (Netherlands Research Centre T.N.O. for Shipbuilding and Navigation). One of the projects on the programme is the specification of lubricants for diesel engines. This work has been carried out as part of an international scheme co-ordinated by the recently founded C.E.C., the European counterpart of the C.R.C. in the United States. Results obtained so far can be summarized as follows [102]: 
(a) the 'total acid number' has little statistical significance as a measure of the acidity of used oils; obviously A.S.T.M. D664 needs revision or replacement;

(b) diesel engine owners ask for a more significant measure of the 'corrosivity' of used motor oils than acid number;

(c) the non-linear increase in the wear rate of cylinders can lead to a catastrophic breakdown of the motor with serious financial consequence. In the opinion of the users, monitoring any incipient 'blow-by' of the individual cylinder would be desirable.

Clearly, the co-operation of marine diesel engine manufacturers, suppliers of lubricants and users will become of primary importance in the near future.

\section{Future trends}

Government expenditure on 'tribology' [103] is considerable when expressed in absolute figures, but it constitutes only a very small fraction of the national effort in education and research. With the latter ranging from qualification of used oil to wear in atomic reactors, the existing system of research should be sufficiently elastic to meet any future specific demands. Consolidation, rather than spectacular growth, can be expected in the following three directions.

The means of communication within the country are already used to capacity. A more systematic exchange of available reviews, and of reviewers, on an international basis would be desirable.

\section{References}

[1] Review Papers, Proc. Instn mech. Engrs 1964-65 $179(\mathrm{Pt} \mathrm{3J})$.

[2] DRESDEN, D. 'Wear research at the National Council of Industrial Research T.N.O.' (in Dutch), T.N.O.-Nieuws 19516 (No. 6), 1.

[3] BLOK, H. Combating wear as a task for the engineer' (in Dutch), 1952, Inaugural Speech, Delft.

[4] ZAAT, J. H. 'Hephaestus in the twentieth century' (in Dutch), 1963, Inaugural Speech, Eindhoven.

[5] DE PATER, A. D. 'On the reciprocal pressure between two elastic bodies' in Bidwell, J. B. (ed.), Rolling contact phenomena 1962, 28 (Elsevier Publ. Co., Amsterdam ).

[6] KALKER, J. J. 'The transmission of force and couple between two elastically similar rolling spheres', Ned. Akad. Wetenschap 196467 (Sec. B), 135.

[7] KALKER, J. J. 'Rolling with slip and spin in the presence of dry friction', Wear 1966 9, 20.

[8] JOHNSON, K. L. 'A review of the theory of rolling contact stresses', Wear 1966 9, 4 .

[9] KALKER, J. J. 'On the rolling contact of elastic bodies in the presence of dry friction', Thesis, T. H. Delft: to be published.

[10] BLOK, H. 'Marginal and partial hydrodyamic lubrication with particular reference to the Conference papers', Proc. Intern Conf. Lubrication and Wear 1957, 198 (Instn Mech. Engrs, London).

[11] BLOK, H. 'Lubrication as a gear design factor', Proc. Intern. Conf. on Gearing 1958, 144 (Discussion, 397, 483) (Instn Mech. Ingrs, London).
The transfer of engineering knowledge from the university level to designers in industry will depend inter alia on the acceptance by designers of modern insight, e.g. due to the application of dimensional analysis and its consequences as a tool in machine design.

Materials research and materials selection pose a rather complex problem. The literature quoted in this paper and corresponding publications from other countries are not the primary source of knowledge for technologists. Invariably they will rely first and foremost on manufacturers' and suppliers' information. A survey [104] shows that the same trend exists in Britain. When suppliers' information is insufficient, technologists will ask for the results of merit-ratings. Because of the operational nature [61-65] of wear problems, the choice of testing depends on the analysis of service conditions, an analysis which has mostly been neglected. But, even worse, until a few years ago the friction and wear processes in laboratory testers had been scarcely analysed; decisive factors, e.g. bulk temperature, relaxation vibrations and atmosphere, remained therefore uncontrolled in testing. Admittedly, the other way, i.e. designing fully instrumented wear testers [70, 72], is both time-consuming and costly. Once such experience is available, testing is easily adapted to specific problems. Bearing in mind that the majority of interested industries in this country are small or medium-sized, a certain time-lag in educating the 'public' to ask the right questions is inevitable. Again, this situation is the same everywhere, as follows from the work of the O.E.C.D. Group on the Wear of Engineering Materials [64].

[12] BLOK, H. 'Hydrodynamic effects on friction in rolling with slippage' in Bidwell, J. B. (ed.), Rolling contact phenomena 1962, 186 (Elsevier Publ. Co., Amsterdam).

[13] BLOK, H. 'The flash temperature concept', Wear 1963 6, 483.

[14] BLOK, H. 'Inverse hydrodynamics', in Muster, D. and Sternlicht, B. (eds) Proc. Intern. Symposium on Lubrication and Wear 1965, 9 (McGutchan Publ. Corp., Berkeley, California).

[15] BLOK, H. 'Topological aspects and the impulsewhirl angle method for studying the hydrodynamic performance of dynamically loaded journal bearings', Lecture Course given to students at T.H. Delft (to be published).

[16] THEYSE, F. H. 'Fundamentals of hydrodynamic lubrication and their conseqences in design engineering', Wear 1964 7, 419.

[17]. THEYSE, F. H. 'Some aspects of the influence of hydrodynamic film', Wear $1966 \mathbf{9}, 41$.

[18] THEYSE, F. H. 'Aspects of gas lubrication' (in Dutch), De Constructeur 1963 1, 30.

[19] THEYSE, F. H. 'Gas as a lubricant' (in Dutch), Instrumentenbouw 196413 (No. 4), 38.

[20] THEYSE, F. H. 'Recent developments in guides and bearings of tooling machines' (in Dutch), De Ingenieur 196577 (No. 18), W51; (No. 20), W61.

[21] THEYSE, F. H. 'Entwicklungen auf dem Gebiete von Flüssigmetall-Umlauf-Kontakten', Arch. techn. Messen 1963 (No. 328), 53 
[22] BARWELL, F. T. Lubrication of bearings 1956, 239 (Butterworths, London).

[23] THEYSE, F. H. 'Summary of research results obtained at the Laboratory for Machine Components', December 1965 (typescript in Dutch).

[24] ROELANDS, C. J. A., BLOK, H. and VLUGTER, J. L. 'A new viscosity-temperature criterion for lubrication oils', Am. Soc. mech. Engrs Paper 64-LUB-3, 1964.

[25] 'The breathing film', based on research work by H. J. Koens: available on loan from the Laboratory for Machine Components, T.H. Delft.

[26] REACTOR GENTRUM NEDERLAND 'Improvement in and relating to pintle thrust bearing', Brit. Pat. Spec. No. 950, 967, published 4th March, 1964.

[27] SCHUTTEN, J., BARON, H., VAN DER HAUW, $T$. and VAN DEENEN, P. J. 'Dynamic measurements of film thickness in gas bearings', Appl. Sci. Res. 19587 (Ser. A), 429.

[28] BOON, E. F. and TAL, S. E. 'Hydrodynamische Dichtung für rotierende Wellen', Chemie-Ingr-Tech. 1959 31, 202.

[29] BARON, H. W. 'Experiments on a glandless seal of the hydrodynamic type for a rotating shaft' (in Dutch), De Ingenieur 196274 (No. 32), W144.

[30] REACTOR CENTRUM NEDERLAND' 'Passage d'arbre étanche aux gaz, pour arbre tournant à grande vitesse', F.P. 1,213,459, published 1st April, 1960.

[31] BARON, H. W. 'The construction of tilting-pad bearings' (in Dutch), De Ingenieur 196375 (No. 47), W191.

[32] MUYDERMAN, E. A. 'Spiral groove bearings', Thesis, T.H. Delft, 1964. Distributed in U.K. and Ireland by MacMillan and Co. Ltd., 4 Little Essex Street, London W.C.2,; 199 pages, 44 sh. In U.S.A. and Canada obtainable from Springer Verlag, 175 Fifth Avenue, New York, \$6.80.

[33] MUYDERMAN, E. A. 'New forms of bearing: the gas and the spiral groove bearing', Philips tech. Rev. 1963-64 25, 253.

[34] MUYDERMAN, E. A. 'Constructions with spiralgroove bearings', Wear 1966 9, 118

[35] MUYDERMAN, E. A. 'New possibilities for the solution of bearing problems by means of the spiral groove principle', Paper 9, Conf. on Lubrication and Wear 1966 (Instn Mech. Engrs, London).

[36] HIRS, G. G. 'The load capacity and stability characteristics of hydrodynamic grooved journal bearings', Trans. Am. Soc. lubric. Engrs 1965 8, 296.

[37] HIRS, G. G. 'Externally pressurized bearings with inherent friction compensation', J. appl. Mech., Trans. Am. Soc. mech. Engrs 196532 (No. 5), 285.

[38] HIRS, G. G. 'Partially grooved, externally pressurized bearings', Paper 21, Conf. on Lubrication and Wear 1966 (Instn Mech. Engrs. London).

[39] HIRS, G. G. 'Grooved bearings and seals, Report 3096, 1965 (The T.N.O. Institute for Mechanical Constructions): Thesis in preparation.

[40] DAVIES, J. W. 'Steplessly adjustable or variable ratio drives', Chart. mech. Engr 196512 (No. 9), 504.

[41] LUDOPH, H. H. J. 'Stepless automatic transmission for cars' (in Dutch), De Ingenieur 196577 (No. 31), W115.

[42] KöHLER, J. W. L. and JONKERS, C. O. 'Construction of a gas refrigerating machine', Philips tech. Rev. 1954-55 16, 105.

[43] PRAST, G. 'A gas refrigerating machine for temperatures down to $20^{\circ} \mathrm{K}$ and lower', Philips tech. Rev. 196526 (No. 1), 1.

[44] SHAIEVITZ, S. 'Cryogenic production of ultra-pure hydrogen', Philips tech. Rev. 196526 (No. 1), 27.
[45] DROS, A. A. 'A refrigerating machine with a hydraulic piston drive for industrial applications', Philips tech. Rev. 1965-66 26 (No. 11/12): in the press.

[46] RIETDiJK, J. A., VAN BEUKERING, H. L. J., VAN DER AA, H. H. M. and MEIJER, R. J. 'A hermetic positive seal for rod and piston suitable for large pressure differences', Philips tech. Rev. 1965-66 26 (No. 11/12): in the press.

[47] VAN ELDIK THIEME, H. C. A. 'Tyre research' (in Dutch), De Ingenieur 196476 (Nos 28 and 30), V81, 91

[48] VAN DER BURGT, G. J. 'The interdependence of car and tyre' (in Dutch), De Ingenieur 196476 (No. 12), V127.

[49] VAN DER VALK, R. 'Tyre construction and materials used' (in Dutch), De Ingenieur 196476 (No. 30), V193.

[50] VAN DER VALK, R. 'Development of motor vehicle tyres with respect to their properties on the road', Rept 65-R4 (Vredestein, Enschede): to be published in Kautschuk Gummi.

[51] PACEJKA, H. B. 'Theoretical and experimental investigation of the shimmy phenomenon' (in Dutch), De Ingenieur 196577 (No. 50), W127; to be published in Proc. Auto. Div. Instn mech. Engrs 1965$66180, \mathrm{Pt} 2 \mathrm{~A}$.

[52] SAVKOOR, A. R. 'On the friction of rubber', Wear $19658,222$.

[53] SAVKOOR, A. R. 'Some aspects of friction and wear of tyres arising from deformations, slip and stresses at the ground contact', Wear 1966 9, 66 .

[54] OBERTOP, D. H. F. 'Relation between friction coefficient and speed on wet surfaces' (in Dutch with a summary in English), Wegen 196135 (No. 4), 92.

[55] Proc. Int. Symposium on Abrasion and Wear (Rubber-Stichting, Holland) 1951; reprinted from Engineering, Lond. 1952 173. Communication No. 211 of the Rubber-Stichting.

[56] BLOK, H. 'War on wear', Proc. Int. Symposium on Abrasion and Wear 1951, 8.

[57] BROEZE, J. J. 'Chemical causes of wear', Proc. Int. Symposium on Abrasion and Wear 1951, 14.

[58] BRUNT, N. A. 'Some investigations of the abrasion of paints', Proc. Int. Symposium on Abrasion and Wear 1951, 25.

[59] SALOMON, G. 'Morphological aspects of abrasion and wear', Proc. Int. Symposium on Abrasion and wear 1951, 19.

[60] BLOK, H. and SALOMON, G. 'Combating wear' (in Dutch), Handel en Industrie, supplement to $\mathrm{Me}$ talen (The Hague), 19549 (No. 2).

[61] SALOMON, G. and BEEKHUIS, D. A. 'A systematic analysis of wear problems' (in Dutch), Part I, Polytech Tijdschr. A 1954 (Nos 25-28); Part II, ibid. 1955 (Nos 1-2).

[62] WAHL, H. 'Standardization in the field of wear' (German and English version), Wear 1957-58 1, 222.

[63] SALOMON, G. 'Editorials', Wear 1957 1, 1, and subsequent volumes.

[64] DE GEE, A. W. J. 'Review of the activities of the O.E.C.D. Group of Experts on Wear of Engineering Materials', Paper R2, Conf. on Lubrication and Wear 1966 (Instn Mech. Engrs, London).

[65] BRIDGMAN, P. W. The nature of some of our physical concepts 1952 (Philosophical Library, New York).

[66] HARPER, F. C. 'The abrasion resistance of flooring material; a review of methods of testing', Wear 1961 4, 461.

[67] INTERNATIONAL STUDY COMMITTEE FOR WEAR TESTS OF FLOORING MATERIALS 
'Performance of abrasion machines for flooring materials', Wear 1961 4, 479.

[68] MAY, W. 'Verbesserte Labor-Bestimmung des Abriebwiderstandes', Kautschuk Gummi, Kunststoffe 196518 (No. 10), 674.

[69] VAN DER VOORDE, C. B. 'On experience with a strut supporting system for testing two-dimensional fully cavitating hydrofoils in a cavitation tunnel' in Symposium on Cavitation Research Facilities and Techniques, 1964, 88 (Am. Soc. Mech. Engrs, New York).

[70] DE GEE, A. W. J., COMMISSARIS, G. P. L. and ZAAT, J. H. 'The wear of sintered aluminium powder (S.A.P.) under conditions of vibrational contact', Wear 1967 7, 535.

[71] DE GEE, A. W. J. and ZAAT, J. H. 'Wear of copper alloys against steel in oxygen and argon', Wear 1962 $5,257$.

[72] DE GEE, A. W. J. 'The friction of gold-silver alloys against steel', Wear 1965 8, 121.

[73] DE GEE, A. W. J. and BEGELINGER, A. 'On the role of oxide formation in sliding friction' (1966): to be published.

[74] WELLINGER, K. und UETZ, H. 'Gleit-, Spül- und Strahlverschleiss-Prüfung (abrasive wear under conditions of sliding, flowing and blasting)', Wear 1957$581,225$.

[75] BRAUER, A. and KRIEGEL, E. ,Wear of feed lines for transport of granular material' (in German), Chemie-Ingr-Tech. 1965 37, 265.

[76] BITTER, J. G. A. 'A study of erosion phenomena', Wear 19636 (Pt I), 6; (Pt II), 169.

[77] FINNIE, I. 'Erosion of surfaces by solid particles', Wear 1960 3, 87.

[78] BOSMA, R. and NAYLOR, H. 'Experimentelle Untersuchung des Umstätterschen StrukturviskositätsEffektes im Zapfengleitlager', Erdöl Kohle 196417 (No. 11), 919.

[79] BROEDER, J. J. and HEIJNEKAMP, J. W. 'Abrasive wear of journal bearings by particles in the oil (apparatus, experiments, and observations)', Paper 13, Fourth convention of the Lubrication and Wear Group, Scheveningen 1966 (Instn Mech. Engrs, London, Vol. 180).

[80] RABINOWICZ, E. Friction and wear of materials 1965 Ch. 7 (Wiley and Sons, New York).

[81] LANCASTER, J. K. 'Anisotropy in the mechanical properties of lamellar solids and its effect on wear and transfer', Wear 1966 9, 169.

[82] SALOMON, G., DE GEE, A. W. J. and ZAAT, J.H. 'Mechanochemical factors in $\mathrm{MoS}_{2}$-film lubrication', Wear 1964 7, 87

[83] DE GEE, A. W. J., SALOMON, G. and ZAAT, J. H. 'On the mechanisms of $\mathrm{MoS}_{2}$-film failure in sliding friction', Trans. Am. Soc. lubric. Engrs 1965 8, 156.
[84] DE GeE, A. W. J. and SALOMON, G. To be published.

[85] JELLINEK, F. 'Sulfides of the transition metals of Groups IV, V and VI', Ark. Kemi 1963 20, 447.

[86] SALOMON, G. 'Grundlagen der Feststoffschmierung' (Fundamentals of lubrication with solids), T.N.O. Nieuws 196621 (No. 2), 39.

[87] Netherlands Patents Nos 88,997 and 88,998 to N.V. De Bataafsche Petroleum Maatschappij.

[88] Netherlands Patent No. 10,340 to Lemet Chromium.

[89] SCHULTZE, W. A. 'Electroplating with iron' (in German), $M T Z 195819$ (No. 11), 1.

[90] SCHULTZE, W. A. 'A contribution to the problem of cylinder wear in marine diesel engines', Shipbldng Progr. 19585 (No. 52), 2.

[91] TORDAY, L. 'Chrome grooves in marine engine pistons', Marine Engnr 1965 (No. 2).

[92] VAN DER ZIJDEN, M. J. and KELLY, A. A. 'Combating cylinder wear and fouling in large lowspeed diesel engines', Trans. Inst. Marine Engrs 195668 (No. 8), 273.

[93] MEADOWS, H. T. Discussion remarks to reference [92], ibid. 280.

[94] STEINBUGH, R. T. 'Nylon 6 as a bearing material', Wear 1962 5, 458.

[95] STEINBUGH, R. T. Private communication, 1966 (Jan.).

[96] BAYER, K. 'Why expansion bearings with "Teflon" were chosen to support the Amsterdam IJ tunnel', J. Teflon (Geneva) 19645 (No. 5), 1.

[97] VAN MOL, H. 'Combating wear by flame-, plasmaand electric-arc spraying', lecture, Amsterdam, 1965 (Nov. 25): to be published.

[98] METAL RESEARCH INSTITUTE T.N.O. The following publications (in Dutch) are from the Centre for Metal Working (1960-1965): Nos 82, 83, 90, 91, $101,104,108,118,121,122,123,124,125$.

[99] 'Meeting of the 'Bond voor Materialenkennis', 21st January 1965, at Geleen. Lectures by the Staff of Staatsmijnen on 'Wear problems and wear prevention at the Staatsmijnen', published partly in Dutch by S. P. Huizinga, Metalen 40 (3) 1966, 90.

[100] DE VRIES, J. 'Practical measures to prevent abnormal wear in a steel mill', Part I, Wear 1957-58 1, 239; Part II ibid. 1958-59 2, 394.

[101] DOPPENBERG, H. 'K.L.M. as a user of oil products' (in Dutch), De Ingenieur 1962 74, M9.

[102] VAN DER HORST, G. W. and DE MOOY, A. 'Report on the activities of the Netherlands Subcommittee „Lubricants for diesel engines" ' 1965 (in Dutch, restricted): to be published in English.

[103] Lubrication (Tribology), Education and Research, Report published by Dept. of Education and Science. London H.M.S.O., February, 1966.

[104] CALDER, N. 'What they read and why', Problems of progress in industry 1959 (No. 4) (Dept. Scient. Indus. Res.; H. M. Stationery Office, London). 